\title{
Journal of Computer Science and Information Technology
}

\author{
https://jcsitech-upiyptk.org/ojs
}

$2022 \quad$ Volume $8 \quad$ Issue $1 \quad$ Hal: 17-21

e-ISSN: 2502-1486

\section{Information System Design in Predicting Production Quantity with the Monte Carlo Method}

\author{
Dinda Ridho Putri Gulo ${ }^{\varpi}$ \\ Information Systems, Faculty of Computer Science, Putra Indonesia University YPTK Padang \\ dindaap0612@gmai1.com
}

\begin{abstract}
Flying Horse Coffee is one of the well-known brands of ground coffee in Padang. Each period this coffee company produces large quantities of coffee, so that the manufacture of coffee only refers to the maker. Therefore, it is important to plan on the amount of coffee production so that the Company does not experience large losses due to the remaining unsold coffee because it is not precise in determining the amount of production. The purpose of this study was to determine the amount of coffee production prediction accurately in preparing the required resources. This study uses Monte Carlo Logic in planning the amount of production. The Monte Carlo method is one of the sciences that developed the same way of thinking as humans and can analyze problems that contain elements of uncertainty. The data that is processed is dat a on demand, supply and production based on the results of per period reports. Results This study uses the Monte Carlo method to predict the amount of coffee production accurately, from testing 44 samples of test data. The Monte Carlo method can predict the amount of production so that it can be used as a recommendation for the Company in predicting the amount of coffee production optimally. And then the company can minimize losses caused by inappropriate production.
\end{abstract}

Keywords: Monte Carlo, PHP, MySQL, Determining, Production.

\section{Introduction}

Along with technological developments in the industrial sector, industrial companies can survive in industrial market competition. To produce optimal production for the company to be more effective and efficient in increasing production by using all available resources. For this reason, it is necessary to plan the amount of production so that the company can provide the right decision on the optimal amount of production.

The Flying Horse Coffee Company is a company engaged in the production of coffee. This flying horse coffee is one of the well-known brands in the city of
Padang, so many consumers like this coffee. Every day or 2 days this company can produce coffee in large quantities. Therefore, a problem arises in the company ob when determining the amount of coffee production that is not yet available, so accurate predictions are needed that aim to obtain maximum profit for the company.

From previous research, the impact of production that problem arises, namely how to predict the amount of is erratic and not in accordance with market demand, production at the flying horse coffee company for the whether on a small, medium, or large scale, will cause future using the monte Carlo method[7]. It is hoped that PTPN VII (Persero) companies to get quite large losses. this application can help companies determine the To overcome this, we need a mechanism to control amount of coffee production so that companies can estimating the number of products to be produced and obtain optimal profits in the production of Flying Horse marketed[1]. One of the previous studies using the Coffee, so from this problem raise the title of the thesis Monte Carlo method can help Ukrainian companies entitled "Designing information systems in predicting predict bankruptcy, so as to improve financial the amount of products that will come in the coffee conditions and reduce the risk of possible bankruptcy. business" flying horse by applying the Monte Carlo The data used are from several companies in Ukraine, method using the PHP programming language and after that the results of all the Monte Carlo method MySQL database.

experiments get a truth level value of $90 \%$ [2]. 


\section{Research Method}

In this study will be explained several things that will be done so as to overcome the existing problems. These stages are a description of the structured research that will be carried out later. With the research methodology can provide convenience for the author in the manufacturing process because the research system becomes more structured. The frame of mind is a rule, tactic and way to gain knowledge. In addition, the framework of thinking can be used to test the true or false of a hypothesis. The real help of researchers from this frame of mind is to incorporate the scientific method, it works in order to find new facts continuously. Apart from the fact that the scientific method has a fixed and tested systematic, it can also review existing knowledge. The framework of this research can be seen in Figure. 1.

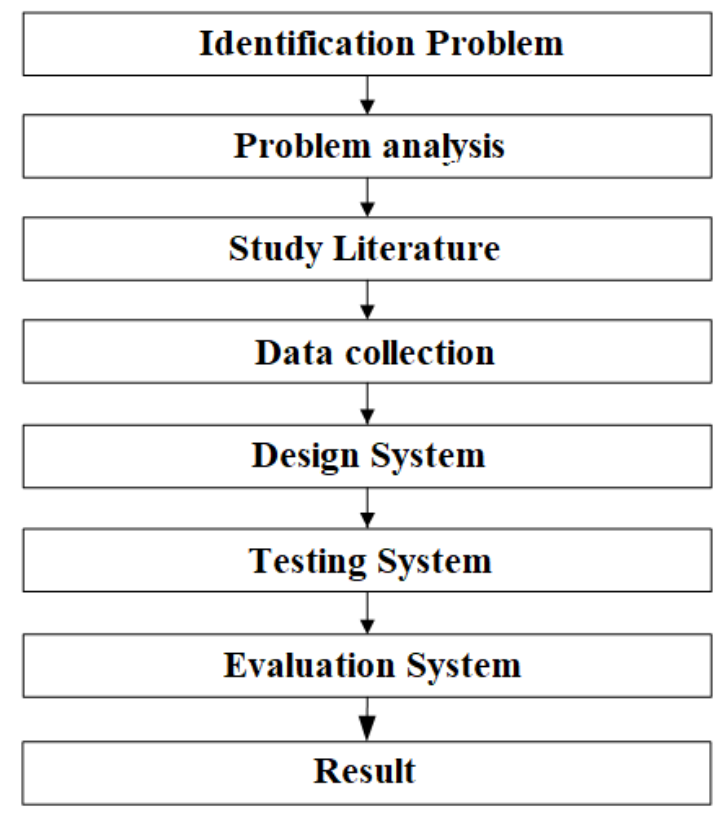

Fig. 1 Research Framework supporting texts. Several models are included in UML modelings such as use case diagrams, class diagrams, activity diagrams, and sequence diagrams[8]. UML is one of the language standards that is widely used in the industrial world to define requirements, make analysis and design, and describe object-oriented architecture[9]. The purpose of using UML is to provide illustrations that are often used in the design of object-oriented information systems, software systems, and software modeling techniques that describe systems in the form of drawings or project development diagrams[10].

\subsection{Modeling and Simulation}

Simulation is a computer program (software) that serves to imitate the behavior of a certain real system (reality). The purpose of the simulation is training (training), the study of system behavior (behavior), entertainment, or games (games). Modeling and simulation are tools that are often used by management in studying or analyzing the work behavior of a system or process[11].

\subsection{Monte Carlo Simulation}

Monte Carlo simulation is defined as all statistical sampling techniques used to estimate solutions to quantitative problems. In a Monte Carlo simulation, a model is built based on the actual system. Each variable in the model has a value that has a different probability, which is indicated by the probability distribution or commonly called the probability distribution function[12].

The Monte Carlo method simulates the system repeatedly, hundreds or even times depending on the system under consideration, by choosing a random value for each variable from its probability distribution[13]. The result obtained from the The description of the framework is a detailed simulation is a probability distribution of the value of a breakdown of each framework that is prepared so that system as a whole. Monte Carlo simulation has been the research carried out can be carried out in a applied to various fields, including; project structured and clear manner. At the stage of testing and management, transportation, computer design, finance, implementation of the data that has been processed with the PHP programming language. It is intended that the designed model can be useful for its users so that the application of the Monte Carlo simulation method will occur in the future. At the evaluation stage of the test data that has been carried out using a Monte Carlo simulation, the results obtained will be evaluated based on the performance of the method used. The results of the simulation will be compared with the existing real data to see the percentage level $(\%)$ of accuracy.

\subsection{UML (Unified Modeling Language)}

UML is a visual language for modeling and communicating about a system using diagrams and meteorology, biology, and biochemistry[14]. The use of the Monte Carlo method requires a large number of random numbers so along with the development of this method, a random number generator has also been developed which turns out to be more effectively used for tables of random numbers which were previously often used for statistical retrieval[15].

\section{Result and Discussion}

\subsection{Analysis and Design}

At this stage, the first step we will do is analyze the system. The purpose of this system analysis is to obtain the optimal prediction results of Flying Horse Coffee 
using Monte Carlo. The Carlo method is an extension of monotonous reasoning. In the Carlo method, every consequence of the IF-THEN rule must be represented by a Monte set with a monotonous membership function. As a result, the inference output of each rule is given in a crisp (crisp) based on the -predicate (fire strength). The final result is obtained using the weighted average.

In processing the data, the data will look into several groups based on the limits that have been given from the research site for the Flying Horse Coffee. In determining the number of coffee predictions there are some data needed. Such as the number of requests, the amount of inventory, and the amount of production. Some of the data that has been collected will be analyzed so that the data will become a Monte set that can be used using the Monte Carlo system. The data taken and analyzed for this research are 44 samples of production data starting from January-March 2019. The format of the data to be processed can be seen in Table.1.

\begin{tabular}{|c|c|c|c|}
\hline Date & Demand & Invento & Production \\
\hline 2 Januari & 534 & 139 & 550 \\
\hline 4 Januari & 572 & 146 & 575 \\
\hline 6 Januari & 466 & 136 & 450 \\
\hline 8 Januari & 313 & 65 & 300 \\
\hline 10 Januari & 185 & 20 & 190 \\
\hline 12 Januari & 505 & 150 & 580 \\
\hline 14 Januari & 585 & 142 & 520 \\
\hline 16 Januari & 242 & 68 & 300 \\
\hline 18 Januari & 583 & 145 & 575 \\
\hline
\end{tabular}

\subsection{Monte Carlo Process Analysis}

From the block diagram above, it can be seen the process that occurs in the Monte Carlo analysis process. The implementation of the above steps is described in the following stages:

\section{A. Montefication}

The process of converting a system input that has a firm value into a linguistic variable using a function stored in the Monte knowledge base.

\section{B. Analysis for Inventory Variables}

Inventory variable has a value that is expressed with conditions of little, medium, and a lot. Where each condition has a predetermined range of values.

C. The Basics of Monte Knowledge Formation (IF...THEN Rule)

D. Monte Carlo forms a rule-based on or a rule base in the form of "cause and effect" or "if-then", while the formation of rules can be seen in Table.2.
Table. 2 Rule

\begin{tabular}{clll}
\hline Date & Demand & Inventory & Production \\
\hline 1 & Down & A little & Reduce \\
2 & Down & Currently & permanent \\
3 & Down & Lots & Increase \\
4 & Permanent & A little & Reduce \\
5 & Permanent & Currently & permanent \\
6 & Permanent & Lots & Increase \\
7 & Up & A little & Reduce \\
8 & Up & Currently & permanent \\
9 & Up & Lots & Increase \\
\hline
\end{tabular}

Table. 2 is a formation table consisting of 3 variables, namely demand, supply, and production. From these 3 variables, 9 rules have formed that function to predict the amount of Flying Horse Coffee production.

\section{E. Inference Engine}

The inference engine is a process to convert Monte input into Monte output by following the rules (IF...THEN Rules) that have been defined based on Monte knowledge. Then use the MIN function to get the value of -predicate $(1,2,3, \ldots ., \mathrm{n})$-predicate is used to calculate the inference output strictly (crisp) (z1, z2, $\mathrm{z} 3, \ldots, \mathrm{zn})$.

\section{F. DeMontification}

At this stage is to find the output value in the form of a crisp value (z) which is known as the defuzzification process. The method used in this process is the Center Average DeMontefier method. The method is described in Equation 1, the deMontification process is carried out by finding the average value (WeightAverage).

\subsection{Accuracy Test Results Using MAPE}

The results of this test work to find accuracy results by using a formula, namely, Mean Absolute Percentage Error (MAPE). After getting the prediction results for the amount of Flying Horse Coffee production using the Monte Carlo method from test data for January 2019-March 2019, then testing using the MAPE method. The results of the prediction of the amount of Flying Horse Coffee production using the Monte Carlo Method can be seen in Table. 3 .

\begin{tabular}{|c|c|}
\hline Monte Carlo & Difference \\
\hline 432 & 118 \\
\hline 527 & 48 \\
\hline 403 & 47 \\
\hline 284 & 16 \\
\hline 150 & 40 \\
\hline 492 & 88 \\
\hline 523 & 3 \\
\hline 294 & 6 \\
\hline
\end{tabular}


Table. 3 is the result of testing using the Monte Carlo B. Display Menu Rules method using a sample of test data from January 2019March 2019, the results obtained are the average MAPE value with an error difference or an error rate of $12.443 \%$, meaning that if the accuracy rate is $100 \%$, the data obtained is tested has a truth rate of $87.557 \%$. So that the Monte Carlo method can be used as a recommendation for companies in predicting the amount of coffee production.

\subsection{System Design}

A use case diagram is a series/description that is interrelated and forms a regular system that is carried out or discovered by an actor. Use Case diagrams are used for the behavior of objects in a model and are realized by a collaboration. The use case itself describes the system processor system requirements from the user's point of view. This diagram can be seen in Fig. 2

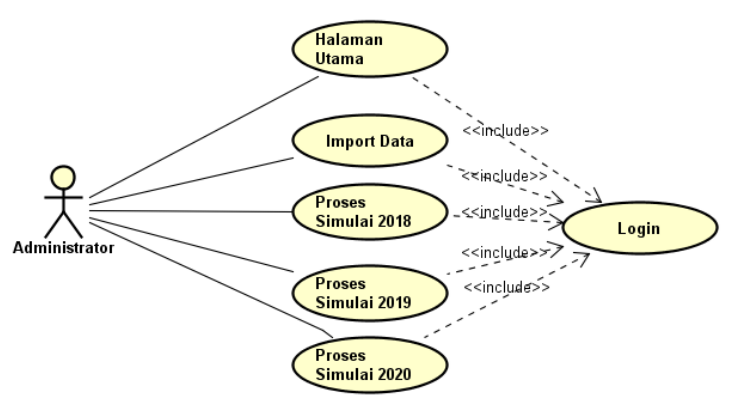

Fig. 2 Usecase Diagram

\subsection{Implementation}

Implementation is an activity carried out to find out how the application that has been built can be applied to a system. In the implementation, an application is needed to predict the amount of Flying Horse Coffee production using the PHP programming language and MySQL database, to run the application it requires hardware and software support which is described in the following sub-chapters:

\section{A. Main Page View}

The main page view is the initial view to access all the menus provided on the display. So that users can access the system as needed. In the production menu, work for the process of predicting the amount of production, then on the report menu, it functions to display the results of the prediction of the amount of coffee production. The main page can be seen in Figure. 3.

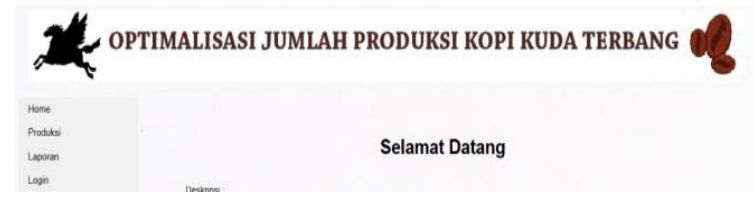

Fig. 3 Main Page Views
This page displays information about the rules used in the process of predicting the amount of Flying Horse Coffee production, the available rules are the requested variable which has 3 sets, namely Down, Fixed and Up, then inventory variable which has 3 sets, namely Few, Medium and Many, Next is the production variable which has 3 sets, namely Decreased, Fixed and Increased. The available rules can be seen in Fig. 4.

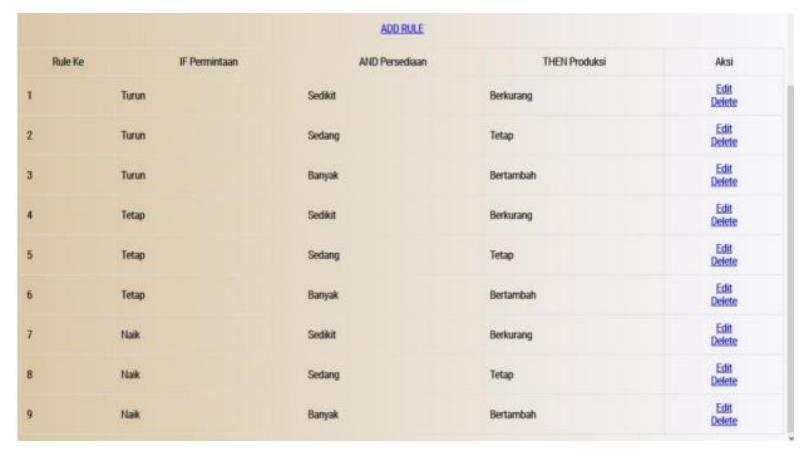

Fig.4 Display Menu Rules

Then to add a rule by clicking the Add rule button, after that the admin will enter the add rule page and input the rules and sets needed in the process of predicting the amount of Flying Horse Coffee production, the display of add rules can be seen in Fig. 5.

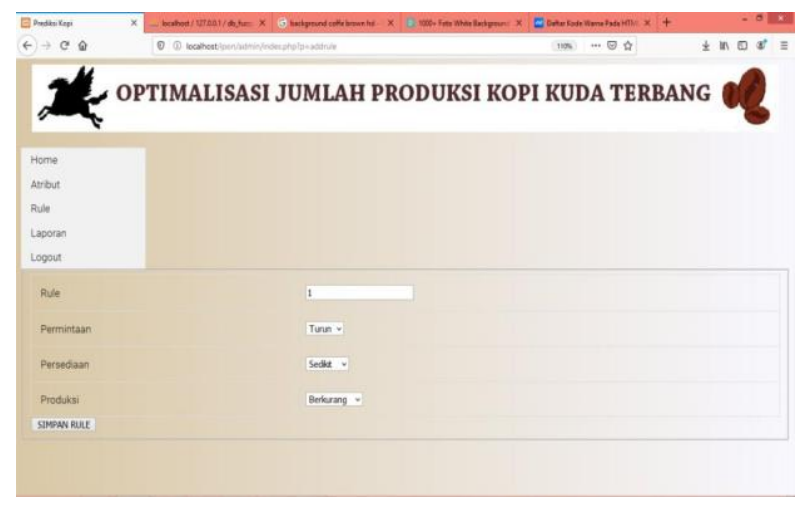

Fig. 5 View Add Rule

After all the data needed by the admin to predict the amount of production as required and the rules that have been set in the system, the prediction process can be done by accessing the production menu and inputting the fields provided by the system.

\section{Production Menu Display}

This page displays the process of predicting production by inputting the name of the clerk, the value of the request, and the value of the inventory, after entering the process click the button, while the display can be seen in Figure .6. 




Fig. 6 Production Menu Display

\section{Report Menu Display}

This page displays information about the predicted results of Flying Horse Coffee which contains information such as official name, demand, inventory, production quantity, status, and production date which can be seen in Figure. 7.

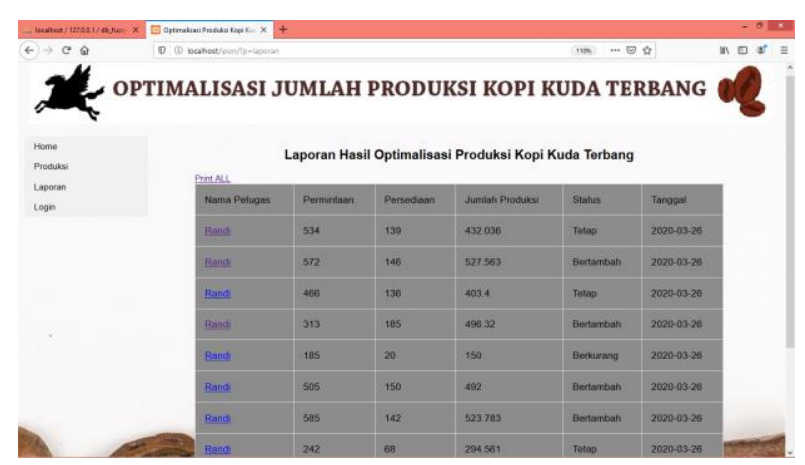

Fig. 7 Report Menu Display

\section{Conclusion}

Based on the research and discussion carried out, it can guarantee several things, namely by applying the Monte Carlo Method to optimizing the amount of production of Flying Horse Coffee, it can help the Company in minimizing losses due to less than optimal production. With the Monte Carlo method, this system has been tested using real data from the company. The results of testing this system have an accuracy rate of $87.55 \%$, so this system can be used as a recommendation for the Company in predicting the optimal amount of coffee production for the future.

\section{References}

[1] Anggya Nanda Soetarmono, 2018 "Perancangan dan pembuatan sistem informasi gedung, Vol 4 No 1

[2] Andri Kristanto, 2018, "Perancangan Sistem Informasi dan Aplikasinya, Yogyakarta

[3] Boko Sosilo, 2018, "Sistem Pendukung Keputusan Untuk Penerimaan Bantuan Pinjaman Samisake Dengan Metode Monte Carlo, Vol 3 No 1 Maret

[4] Eko Budi Setiawan, 2018, Pengolahan Sistem Informasi Pengolahan Data Pencarian Kerja Pada Dinas Sosial dan tenaga Kerja Kota Padang".

[5] Endra Rahmawati, Rancang Bangun Sistem Informasi Administrasi Akdemik Berbasis Web Pada SMA Ta'mariyah Surabaya, 2019

[6] Erna Susanti, 2018. Sistem Informasi Pelayanan (BPJS) Berbasis Web, Jurnal Teknik A, ISSN: 2085-0859 Vol. 6 No.2 September 2018

[7] Firna Yenila, 2018, "Sistem Pakar Mediator Dalam Sengketa Perceraian",

[8] Fathansyah, 2018, "Basis Data", Informatika, Bandung.

[9] Gerogoe M. Marakas, 2017, Pengantar Sistem Informasi, Jakarta

[10] Raka Tut Huru. 2019. Analisis serta Perancangan Sistem Informasi melalui Pendekatan UML. Yogyakarta: CV. Andi Offset.

[11] Ramadhani, Cipta, 2018, "Dasar Algoritma dan Struktur Data dengan Bahasa JAVA", Yogyakarta.

[12] Sarosa Samiaji, 2017, "Metedologi Pengembangan Sistem Informasi, Yogyakarta.

[13] Xaverius Najoan, 2019, "Sistem Informasi perpustakaan online berbasis web".

[14] Zefriyeni, "Sistem Informai Penjualan dan pengendalian persediaan barang menggunakan metode monte carlo menggunakan bahasa pemrograman java dan database mysqlpada toko kensa elpiji", Vol. 2, No 2 Desember 2018Teachers. SAGE Open, 8(4), 215824401880921. doi:10.1177/2158244018809216. 